\title{
A Comparative Analysis of Municipal Waste Management Systems
}

\author{
Grzegorz Przydatek* \\ State Higher Vocational School, Technical Institute in Nowy Sącz \\ Zamenhofa 1a, 33-300 Nowy Sącz, Poland
}

Received: 29 December 2015

Accepted: 16 February 2016

\begin{abstract}
Waste management is important in the activities of local authorities. Therefore, attention to waste management is reflected in the nature of a commune. The system analysis of chosen waste management is significant due to the need to improve the activities undertaken to achieve the best results.

The aim of such a work was a comparative analysis of the efficiency of waste commune systems in two local government units within the Małopolska region of Poland.

The subjects of comparative analysis of waste management systems were two selected communes of different sizes located within the same county. The study included the quantity and quality of collected municipal waste and indicators of their accumulation in 2007-10. On the basis of the conducted analysis that the inhabited commune had a larger number of inhabitants and with a larger surface area, the waste disposal was carried out more frequently by a substantial amount of subjects. The commune has also identified significantly more than 3.5 times the average of total waste.

In both communities and regardless of the noted differences a growing trend of the quantities selectively waste collected were about $32 \%$ lower in the commune with fewer inhabitants, in which waste collection of paper and cardboard generated no result. Generally conducted in both communes, recovery contributed for favorable weight limitations the assembled waste on an average of $30 \%$. Dealt with in the period of waste accumulation indicators begins to differentiated an average increase of $14 \mathrm{~kg} \cdot$ person $^{-1} \cdot \mathrm{year}^{-1}$, and $2 \mathrm{Mg} \cdot \mathrm{km}^{-2}$ in favor of more commune. As significant was in the municipality of year 2009, in which it were achieved the highest values of amounts of the collected the and sent to the assembled waste, the highest indicators of waste accumulation, in despite of made note the highest number of inhabitants in the next year.
\end{abstract}

Keywords: municipal waste, collection, waste management

\section{Introduction}

Where the quantity of municipal waste is increasing with development, a serious threat to the environment in posed, in particular with "wild landfills". This affects

*e-mail: g.przydatek@gmail.comIntroduction the decrease in the efficiency of the waste management that according to Sołowiej [1] is a consequence of the low level of recovery of the collected waste, as well as the low environmental awareness of the general public. In this context, and in accordance with the legislation of the European Union set up to improve the quality of the environment have taken into account in the design 
of Environmental Policy the Member States contained in the Resolution of the Sejm of the Republic of Poland of 22 May 2009 [2]. They indirectly influenced for change, providing all inhabitants with the obligation of the receipt for municipal waste.

The communes, as owners of waste under the provisions of the Act of September 13, 1996, on maintaining cleanliness and order in communes [3], from the half of 2013 were obliged for the implementation of waste management, including the establishment of selectively waste collection in achieving the required levels of recovery and recycling them for the benefit of the reduction of quantity of the assembled waste [4]. This determined the hierarchy of waste treatment, including preventing their formation after disposal. This hierarchy is to optimise the management of solid waste from a variety of sectors, including household waste [5]. The need to reduce the quantity of generated waste, and at the same time increasing the levels of recovery, require leading at the commune level separate collection, which should include the receipt of the basic fraction of waste such as paper, metal, glass and plastics, multimaterial and biodegradable waste, including waste biodegradable packaging.

Introduced in recent years, changes to the Act of 27 April 2001 on waste [6], contributed to the repeal of the requirement to develop waste management plans at the level of county and at the commune level. The waste management plan at the voivodeship level includes the duties of the communes with regard to municipal waste management. It should be noted that the change was a consequence of the non-accelerating of the development and adoption of plans at the commune level [7].

A comparison system of waste management in the various settlement units at the local level, should favor an improvement in the efficiency of their implementation. An important remains solutions of your problems with the planning and selection of the structure of the waste management system, which is a multistep process consisting in identifying the differences and elements of common variant solutions, in selecting the most beneficial solutions, in choosing the most advantageous of solutions [8], for reaching expected levels of recovery and waste recycling.

\section{Material and Methods}

The aim of such work was a comparative analysis of the efficiency of waste commune systems in two selected local government units in Małopolska. The research in the period 2007-2010 has been included of the Łapanów and Trzciana communes in terms of quantity and quality of collected non - selectively and selectively municipal waste, including paper and cardboard, glass, plastics and metal.

The study was based on obtained data from two communes, including statistics and observations. A comparative analysis had been carried out taking into account the results of the waste accumulation, disposal systems, the number of inhabitants and the surface of the mentioned communes.

\section{Characteristics of the Study Communes}

The studied units located in close proximity to Bochnia County, that belong to the typical agricultural production. The Łapanów commune covers an area of 7170 ha and Trzciana covers an area of 4409 ha. In the first commune participation of persons using the water supply system took out $68.4 \%$, from the sewage system $23.1 \%$, and gas network of $68.1 \%$. In the second commune these shares amounted appropriately $0 \%, 5.9 \%$ and $77.5 \%$. The area of the first commune is singled out of the Special Area of Conservation of the Natura 2000 site - Tarnawka covers an area of 139.95 ha, but in second one Nature Reserve "Kamionna" covers an area of 64 ha [9]. There is the Major Groundwater Reservoirs no 442 "Stradomka Valley" on the area of studied units. Moreover, it is characterized by a varied relief and significant landscape values. Belonging mainly to individuals, single buildings with living quarters prevailed in local government units.

\section{Results of Investigation}

The studied results were included in tables (Tables 1-3), as well as in the graphic form (Figs 1-6).

The average number of inhabitants in the period 2007 2010 in the Łapanów commune was higher about 2322 people relative to the taken note average in Trzciana commune (tab.1). In the communes, generally an increase in the number of inhabitants can be recorded, on average, 131 people.

Receipt of collected non-selectively waste at the first mentioned commune was ensured by four operators. This waste was put in plastic bags and containers for capacity $120 \mathrm{dm}^{3}$ like municipal waste produced in the infrastructure facilities with the exception of cemeteries, where containers were being used of $6.5 \mathrm{~m}^{3}$. Waste produced by business entities was also put into bags and containers.

The selective waste collection on this area was conducted by two export companies. Selectively gathering waste which was produced in households and in educational institutions used colored bags (capacity of $120 \mathrm{dm}^{3}$ ). Moreover the containers of the type «bell» the capacity of $2.2 \mathrm{~m}^{3}$ were located in the neighborhood of the educational institutions, gathering waste paper, glass and plastics.

Table 1. Population of the Łapanów and Trzciana commune in $2007-2010$

\begin{tabular}{|c|c|c|c|c|c|}
\hline \multirow{2}{*}{ Commune } & \multicolumn{4}{|c|}{ Year } & \multirow{2}{*}{ Average } \\
\cline { 2 - 5 } & 2007 & 2008 & 2009 & 2010 & \\
\hline Łapanów & 7461 & 7518 & 7533 & 7630 & 7536 \\
\hline Trzciana & 5168 & 5187 & 5239 & 5261 & 5214 \\
\hline
\end{tabular}




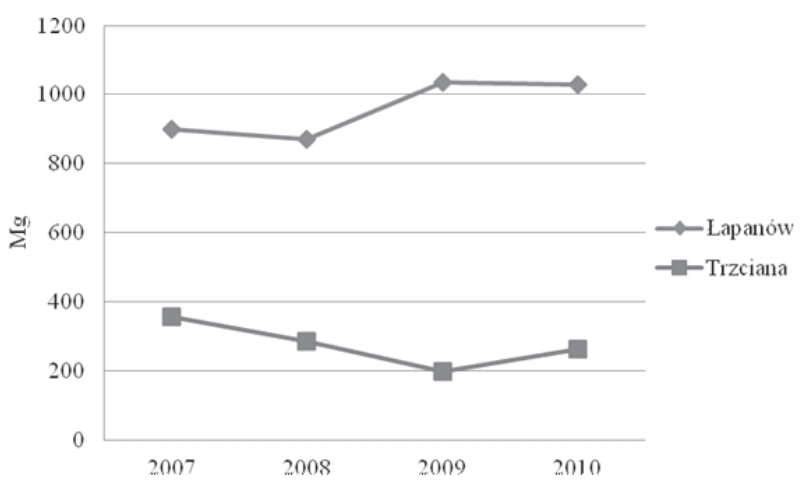

Fig. 1. A variable quantity of the collected municipal waste.

The assembled non-selective municipal waste was divested 1 time in the month in the period November March, and in the other period 2 times in the month. 1 time within a month there were collected selectively fractions.

Produced in the households waste in the commune of smaller size was collected by one carrier which previously was being put in the bags. Similarly, produced municipal waste in the facilities and infrastructures by established entities were placed in bags. Moreover exchangeable containers were being used. In the second commune by export company carried out the receipt of selectively collected waste. For selective collection, waste in households and in educational establishments used colorful bags.

The collected non-selectively and selectively waste were disposed of at least 1 time in the month. In the area of communes being the subject of the research generally it is possible to distinguish the following systems of municipal waste collection:

- non-selective waste collection

- selective waste collection for the raw material recycling.

In both communes unexchangeable containers and bags were a dominating solution serving the accumulation of waste. Exchangeable containers were applicable only in case of objects of the infrastructure and business entities. Generally the manner of the waste disposal can be carried

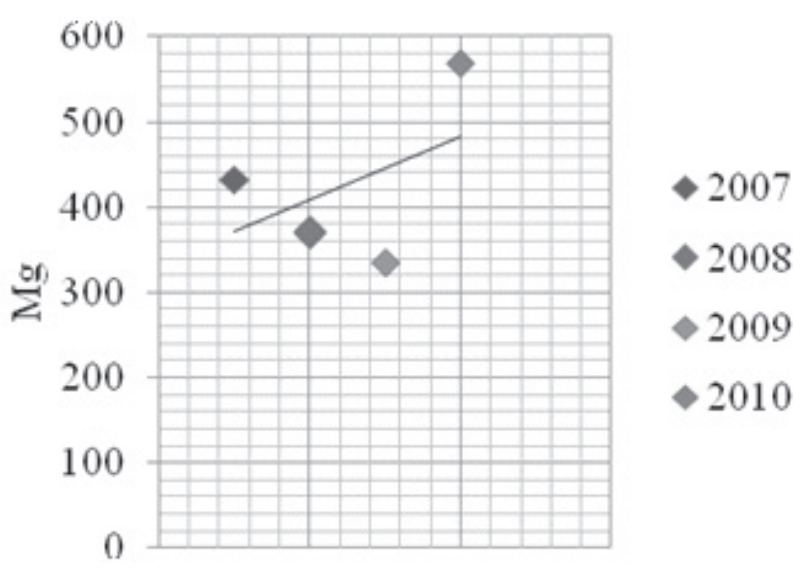

Fig. 2. Increase of quantity of selectively collected waste in the chosen communes.

out by system the unexchangeable and exchangeable containers, including the swapping of them [10]. More often, because the 2-times per month were divested mixed waste from the commune of greater area. Moreover, 1 time per month was divested waste from both communes collected selectively waste, as well as non-selectively one with the commune with a fewer population.

Fig. 1 shows a variable quantity of the collected municipal waste in the period 2007-2010. On the commune with a larger population the amount of waste ranged from $872 \mathrm{Mg}$ to $1035 \mathrm{Mg}$ on an average of $95 \mathrm{Mg}$, and in smaller numbers from 197.1 to $355.3 \mathrm{Mg}$ on an average of $275 \mathrm{Mg}$. The maximum and minimum and including the quantity of received waste respectively from Łapanów commune and Trzciana one in the same year. Such an increase was also observed in Austria, Ireland and Sweden since 2003 [11].

This have an impact on many factors: the number of inhabitants, the degree of urbanization, the degree of equipment in the technical infrastructure (water supply, sewage, heating) [12]. The first mentioned government unit distinguished over 3.5 - times advantage of the amount of gathered waste in relation to the second analysed unit, in which the fall in the amount of collected waste.

Table 2. The volume of selectively collected waste in 2007-2010.

\begin{tabular}{|c|c|c|c|c|c|c|c|}
\hline \multirow{3}{*}{ Commune } & \multirow{3}{*}{ Waste code } & \multirow{3}{*}{ Type of waste } & \multicolumn{4}{|c|}{ Year } & \multirow{2}{*}{ Average } \\
\hline & & & 2007 & 2008 & 2009 & 2010 & \\
\hline & & & \multicolumn{5}{|c|}{ Amount [Mg] } \\
\hline \multirow{4}{*}{ Łapanów } & 200102 & Glass & 1.0 & 69.0 & 93.0 & 119.0 & 70.5 \\
\hline & 200101 & Paper and cardboard & 42.5 & - & - & 0.4 & 21.5 \\
\hline & 200139 & Plastics & 4.9 & 13.0 & 17.0 & 23.0 & 14.5 \\
\hline & 200140 & Metal & 284.4 & 217.0 & 160.0 & 361.0 & 255.6 \\
\hline \multirow{3}{*}{ Trzciana } & 200102 & Glass & 71.3 & 42.3 & 53.0 & 49.7 & 54.1 \\
\hline & 200139 & Plastics & 13.3 & 14.2 & 7.0 & 11.8 & 11.6 \\
\hline & 200140 & Metal & 15.0 & 16.0 & 5.1 & 4.2 & 10.1 \\
\hline
\end{tabular}


Table 2 shows the volume of selectively collected waste in the years 2007-2010. The total amount of recovered waste in the commune Łapanów in that period ranged from 270 to $503.4 \mathrm{Mg}$ on an average of $351.3 \mathrm{Mg}$. The largest mass of the collected recyclables materials have been reported in 2010, and the smallest in 2009 . Observed over a period of 4 years an increase of the quantity of assembled waste in commune amounted to $170.6 \mathrm{Mg}$. In the second mentioned commune this quantity ranged from 65.7 to $99.7 \mathrm{Mg}$, on an average of $25.2 \mathrm{Mg}$. The largest mass of sorted waste was declared in this commune in 2007, and smallest in the last analysed year. The decrease in quantity of selectively collected waste amounted to $33.9 \mathrm{Mg}$.

Fig. 2 shows the increase of quantity of selectively collected waste in the chosen communes. The total amount of selectively collected waste in the mentioned municipalities ranged from 335.1 to $562.12 \mathrm{Mg}$. The change in quantity of collected ,at source" of waste paper and cardboard, glass, plastic and metals in the studied communes shows growth in the years 2007-2010 on an average of $427 \mathrm{Mg}$.

Figs 3 and 4 show share fractions of selectively collected waste in the Lapanów commune and in the Trzciana commune. The largest $73 \%$ share of the mass of selectively gathered waste fell to waste of metal, and lowest of $3 \%$ to waste of paper and cardboard. In the case of metals the level of recovery considerably exceeded the appointed level of 5\% in the Waste Management Plan of Małopolska Voivodship [13]. In the second commune a receipt of waste paper and cardboard wasn't recorded. According to Kubonia [14] paper and cardboard packaging in most households are sent to incineration, which reduces the level of their recovery. The highest $72 \%$ participation of selectively waste collected in the second of the commune analyzed fell to glass and $15 \%$ fell to plastics while the lowest $13 \%$ to metal. This reflects the national trend, in which all but a significant recovery of plastic it was also an increase in participation of the collected glass [7]. A similar level of recovery of plastics were recorded in Malaysia[15], [16]. In contrast, the studies conducted in the United Kingdom have shown significantly lower proportion of metal and glass in the composition of the waste [17]. More than four-times the advantage of selectively collected waste fell to the first commune. For the benefit affects of the larger quantity of collected waste metal about - $982.1 \mathrm{Mg}$, glass about $65.7 \mathrm{Mg}$ and plastics $-11.6 \mathrm{Mg}$. Glass as a material has a very good properties (stable, effective, and reuse and recycling of materials,

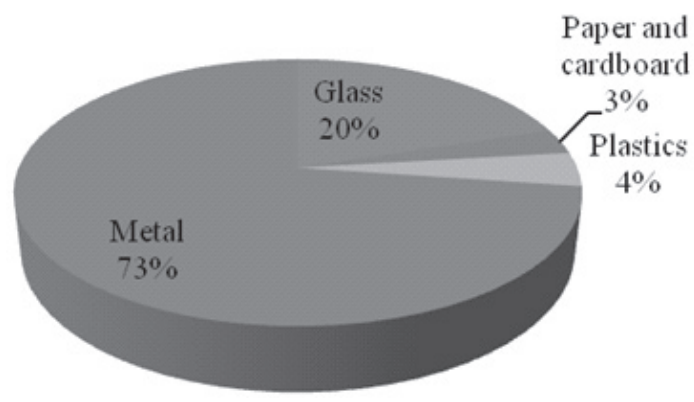

Fig. 3. The share fractions of selectively collected waste in the Łapanów commune.

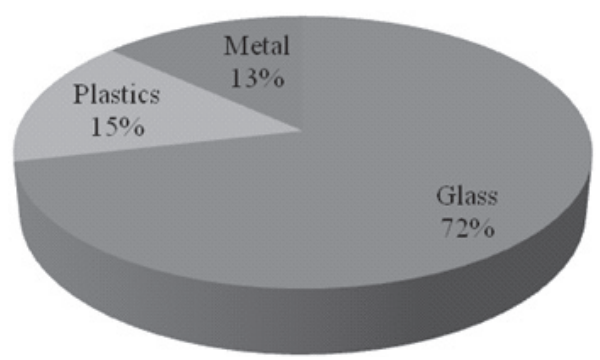

Fig. 4. Share fractions of selectively collected waste in the Trzciana commune.

made from inorganic materials, so there is no negative impact on the environment, cheap raw materials) [18].

Table 3 shows the quantity of mixed municipal waste sent to disposal in 2007-2010. The quantity of mixed municipal waste sent to the disposal from the Łapanów commune in the years 2007-2010 ranged from 526 to $765 \mathrm{Mg}$ with an average of $607.8 \mathrm{Mg}$. The largest mass of waste sent to landfill has been observed in 2009, at least in 2010, which confirmed generally decrease of 41 $\mathrm{Mg}$. In the second commune that was analyzed, the mass of waste sent to disposal ranged from 132 to $255.6 \mathrm{Mg}$ on an average of $199.7 \mathrm{Mg}$. The largest quantity of that waste has been sent to disposal in 2007, and the lowest in 2009 , which also showed a decrease of $57.3 \mathrm{Mg}$. Reduce the amount of waste sent to disposal is accordance with the trend occurring in the European Union, where there is a noticeable increase in the proportion of recovered waste.

Waste segregation in the Lapanów commune in years 2007-2010 has caused limitation to the quantity of sent to disposal on an average of $37 \%$, within in the Trzciana commune on an average of $28 \%$. To compare the level

Table 3. The quantity of mixed municipal waste sent to disposal in $2007-2010$

\begin{tabular}{|c|c|c|c|c|c|c|c|}
\hline \multirow{3}{*}{ Commune } & \multirow{3}{*}{ Waste code } & \multirow{3}{*}{ Type of waste } & \multicolumn{4}{|c|}{ Year } & \multirow{2}{*}{ Average } \\
\hline & & & 2007 & 2008 & 2009 & 2010 & \\
\hline & & & \multicolumn{5}{|c|}{ Amount of waste[Mg] } \\
\hline Łapanów & \multirow{2}{*}{200301} & \multirow{2}{*}{ Mixed municipal waste } & 567 & 573 & 765 & 526 & 607.8 \\
\hline Trzciana & & & 255.6 & 213 & 132 & 198.3 & 199.7 \\
\hline
\end{tabular}




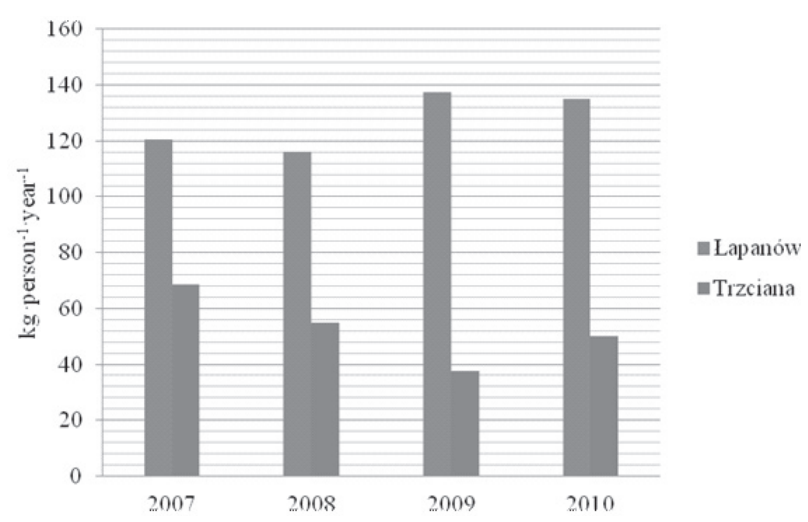

Fig. 5. The changes of the indicator of mass municipal waste accumulation in 2007-2010.

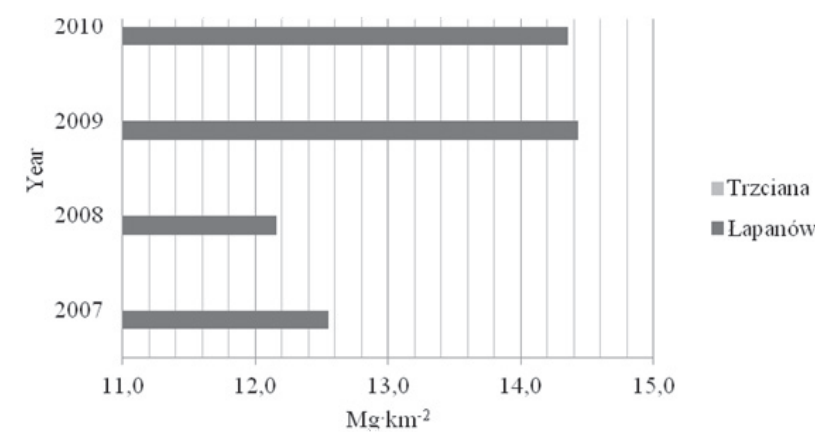

Fig. 6. The changes of the indicator of municipal waste accumulation per unit area in 2007-2010.

of processing waste from separate collection in Norway amounted to an average of $68 \%$ [19] and in Turkey less than $5 \%$ [20].

Fig. 5 shows the changes of the indicator of mass municipal waste accumulation in 2007-2010. The indicator of the mass municipal waste accumulation in the Lapanów commune was located within the limits of 116 - $137 \mathrm{~kg} \cdot$ person $^{-1}$ year $^{-1}$ and has taken note an increase on an average of $127 \mathrm{~kg} \cdot$ person $^{-1} \cdot \mathrm{year}^{-1}$. In the second studied commune this indicator amounted from 38 to $69 \mathrm{~kg} \cdot$ person $^{-1} \cdot \mathrm{year}^{-1}$ and decrease on an average of $53 \mathrm{~kg} \cdot$ person $^{-1} \cdot$ year $^{-1}$. The studies has shown that the average amount of waste per capita of the Lapanów commune was $74 \mathrm{~kg} \cdot$ person $^{-1}$ year ${ }^{-1}$ higher than in relation to the value of the indicator relating to the compared commune. The average values of the indicator were lower than the average per capita Greece, which amounted to $475 \mathrm{~kg} \cdot \mathrm{m}^{-1} \cdot \mathrm{rok}^{-1}$. According to Indris et al. [21] and Żygadło [22] indicators of waste accumulation subject to fluctuations and depend on the level of consumption societies and also of the waste collection system, in a given area.

Fig. 6 shows the changes of the indicator of municipal waste accumulation per unit area in 2007-2010. The average indicator of waste accumulation per unit area for the Lapanów commune amounted of $13.4 \mathrm{Mg} \mathrm{km}^{-2}$, and for the Trzciana commune was lower and amounted of $6.2 \mathrm{Mg} \cdot \mathrm{km}^{-2}$. The commune with a larger surface distinguishes, the growing trend of analysis indicator, while the second decrease on an average of $7.1 \mathrm{Mg} \cdot \mathrm{km}^{-2}$.

\section{Conclusions}

On the basis of the conducted comparative analysis of municipal waste management, it is possible to express the following conclusions:

- the first mention of the commune is distinguished by its greater surface area and number of inhabitants

- in relation to the second of the studied unit in first the receipt of municipal waste per month took place in the scale of the month 2 - times more often, 3.5-times there was advantage of the amount of accumulated waste, over 4 - times advantage of mass of collected selectively waste, higher indicator of mass gathering waste on an average $74 \mathrm{~kg} \cdot$ person $^{-1} \cdot \mathrm{year}^{-1}$ and collecting its per unit of area on an average of $7.1 \mathrm{Mg} \cdot \mathrm{km}^{-2}$,

- within a period of 4 years indicated a favorable trend decline in the quantities supplied to disposal waste on an average of $49 \mathrm{Mg}$

- a variable quantity of selectively collected recyclable materials has been shown an increasing trend on an average of $427 \mathrm{Mg}$,

- the conducted recovery of waste caused limitation, the quantity of deposited waste on an average of $32 \%$, with an upward trend in Łapanów commune,

- the largest mass of gathered and passed to disposal waste and the highest values of indicators were achieved in the commune about larger analyzed parameters in 2009 in spite of a significant increase of the number of inhabitants in 2010,

- introduced system changes in the waste management on the commune rank should support increasing the recovery of collected waste "at the source" in the coming years, including reaching required levels of recovery and waste recycling, including commune of a smaller area and population.

\section{References}

1. SOŁOWIEJ P., Municipal waste management in the chosen commune. Ecological Engineering, 7 (297-303), 2005 [In Polish].

2. Resolution of the Sejm of the Republic of Poland of 22 May 2009 on accepting of the document "Ecological Policy in the years 2009-2012 with perspective to 2016 [In Polish]

3. The Act of September 13, 1996 about keeping the purity of order in communes (O.J. 2012, item 391 as amended) [In Polish].

4. PRZYDATEK G., Evaluation of the waste selective collection on the example of the chosen commune. Infrastructure and Ecology of Rural Areas, 3 (03), 209, 2013 [In Polish].

5. MOHD A.A.S., LATIFAH A.M., AMIMUL A., WAN NOR AZMIN S., P. AGAMUTHU, JEFFREY L. D. Household Solid Waste Composition in Balakong City, Malaysia: Trend and Management. Pol. J. Environ. Stud. 22 (6), 1807, 2013. 
6. The Act of 27 April 2001 on waste (O.J. 2012, item 21) [In Polish].

7. SZYMAŃSKA-PULIKOWSKA A., Contemporary problems in planning the waste management. Infrastructure and Ecology of Rural Areas, 3 (03), 209, 2012 [In Polish].

8. BARLAZ M., CEKANDER G.C. , VASUKI N.C Integrated solid waste management in the United States, J.Environ. Eng. 129 (7), 583, 2003.

9. The Central Statistical Office of Poland 2008-2011 Environmental protection [In Polish].

10. PRZYDATEK G., Analysis of system changes in the management of the municipal waste on the commune rank. Autobusy. 10, 109, 2012 [In Polish].

11. European Environment Agency (EEA). Managing Municipal Solid Waste-A Review of Achievements in 32 European Countries. Report No. 2/2013. EEA, Copenhagen, 19 May 2013. Luxembourg, Publication Office of the EU, 2013 (doi: $10.2800 / 71424)$.

12. TAŁAŁAJ I.A., Analysis of changes in the quantities of municipal waste in Podlaskie Voivodeship. Infrastructure and Ecology of Rural Areas. 14, 163,2010 [In Polish].

13. The Plan of Waste Management for the Małopolska Voivodeship. Resolution No. XXV/397/SWM 12 of July 2, 2012 [In Polish].

14. KUBOŃ M., Waste management in agricultural holdings. Ecological Engineering 6 (104), 83, 2008 [In Polish].
15. BADGIE D., SAMAH M A.A., MANAF L.A., MUDA A.B., Assessment of Municipal Solid Waste Composition in Malaysia: Management, Practice, and Challenges Pol. J. Environ. Stud. 21 (3), 539, 2012.

16. HAMID K.B.A., ISHAK M.Y., SAMAH M.A.A. Analysis of Municipal Solid Waste Generation and Composition at Administrative Building Café in Universiti Putra Malaysia a case study. Pol. J. Environ. Stud. 24 (5), 1969, 2015.

17. BURNLEY S.J. A review of municipal solid waste composition in the United Kingdom. Waste Management 27 (1), 1274, 2007.

18. GRUM D., Packaging waste management and environmental safety 55 (1), 37, 2013 [In Croatian].

19. DOCKSAI RICK A., World without Waste Futurist 48 (2), 16, 2014.

20. ÖZBAY İ., Evaluation of Municipal Solid Waste Management Practices for an Industrialized City. Pol. J. Environ. Stud. 24 (2), 637, 2015.

21. IDRIS A., INANC B., HASSAN M.N., Overview of waste disposal and landfills/Dumps in Asian Countries J Mater Cycles Waste Management, 6, 104, 2004.

22. ŻYGADŁO M., Management of municipal waste. Kielce University of Technology, 300, 2002 [In Polish]. 